\title{
It is a Wild Wild World: (Political) Satire in Fielding's Jonathan Wild
}

\author{
Hakan Yılmaz \\ Hacettepe University \\ E-mail: hknylmzz@gmail.com
}

\section{Doi:10.5901/mjss.2013.v4n11p503}

\begin{abstract}
Henry Fielding, deemed one of the fathers of the English novel, had a strong affinity for satire in his works, unlike his prominent novelist peers like Defoe and Richardson. Fielding's literary stance was heavily oriented towards the dominant genre of the poetry of the time, namely, that of the Age of Reason - which criticized and at times lampooned the follies of the age as well as the prominent figures of the time. In this regard, Fielding's adoption of this satiric style - which he used for satirizing the politics of his age - was quite innovative for, and at the same time incompatible with the idea of novel at the time which necessitated the creation of an illusion of reality. Instead, Fielding's highly caricaturized characters for the sake of satire were a far cry from the rigorous attempts of the 18th century realist novelists to delineate their characters as true to life as possible. Moreover, his light-hearted parodic prose constituted attacks on the major political figures of his age - which was unheard of in the newly emerging novel genre at the time and, as Claude Rawson (2008) aptly remarks, "turned Fielding into the principal inventor of the English comic novel" (Introduction, p. xi). Hence, this paper aims at exploring Fielding's impressive political satire on Robert Walpole, the first prime minister of Britain, in his novel Jonathan Wild, and at examining how Fielding, with an extremely satiric purpose, turns topsy-turvy the ideas of high and low, respectable and disrespectable as well as good and bad.
\end{abstract}

Keywords: Henry Fielding, Jonathan Wild, political satire, parody, $18^{\text {th }}$ century English novel

Henry Fielding, one of the key figures in the development of the early English fiction, had a keen eye for affectation, hypocrisy, falsity and insincerity prevailing in any stratum of the society from top to bottom, and herewith definitely a sharp pen to delineate and lampoon such abuses conducted by the members of the society in his works ranging from the pieces published in the magazines and journals of the time to his plays and novels. At times, Fielding was in financial crises which forced him to write for money, as was the case with Daniel Defoe 20 years earlier. As William Irwin (1946) notes, "[a]lthough not impoverished, Fielding was in some ways a hack, working under the pressure of popularity" (p.180). When combined with the fact that "his observation was active and his learning extensive" (Irwin, 1946, p.180), this pressure of popularity and the need of money, in effect, can rightly be taken as the impetus behind Fielding's rigorous attempts to employ in his work what he knew best: satire. The eighteenth century literary scene was saliently characterized by the predominant forms of satire which culminated in the works of Pope (Dunciad), Dryden (Mac Flecknoe) and Swift (Gulliver's Travels), and Henry Fielding had an affinity for the works of these writers. As Claude Rawson (2008) states, "[Fielding's] tastes and his cultural outlook were extensions of theirs" and "[h]is praise of Swift's writings, and his sense of Swift as one of his own great literary masters, along with (and perhaps surpassing) Aristophanes, Lucian, Rabelais, and Cervantes, was strong" (Introduction, p. x). Fielding's adoption of their stylistic manner was to develop to its limits in his novels in which he came up with a new genre that he called in the Preface to Joseph Andrews (1742) "comic epic poem in prose" and defined it as "differing from comedy, as the serious epic from tragedy: its action being more extended and comprehensive; containing a much larger circle of incidents, and introducing a great variety of characters" ( $p$. xxxii). He continues to assert that it introduces light and ridiculous action, persons of inferior rank and inferior manners, and ludicrous sentiments and diction although at times, especially in the depiction of battles, it might naturally parody the high diction of epic and romance ( $p . x x x i i)$. In this regard, Fielding brought a manner totally incompatible with the idea of novel at the time which necessitated the creation of an illusion of reality. This "urbanely interventionist rather than self-effacing manner" that Fielding employed, as Rawson (2008) argues, "contributed to the establishment of a rival narrative mode, more dedicated to displaying a controlling authorial personality than that of Fielding's two main predecessors, Daniel Defoe and Samuel Richardson" and consequently "turn[ed] Fielding into the principal inventor of the English comic novel [. . .]" (Introduction, p. xi). Indeed, what Fielding suggests for his new kind of writing fulfilled its objectives in that he aptly appropriated the characteristics of satire into the novel genre which helped develop his own distinct style. In this paper, Fielding's Jonathan Wild the Great will be examined and discussed in detail 
with regards to the use of parody and satire, especially political satire, by providing many examples from the text.

Henry Fielding was born in Somerset in 1707. He spent most of his childhood in Dorset in a farm under the care of his mother since his father was more frequently than not away "on active service, or on pleasure trips in Ireland and London" (Bree, 1996, p.3). After his mother died in 1718, Fielding along with his numerous siblings suffered abuses and maltreatment at the hands of a step-mother. Fielding's maternal grandmother managed to take the custody of the children to bring such maltreatment to a halt. Later, "sent to Eton against his will," as Howard M. Jones (1950) states, "Fielding nevertheless there laid solid foundation of classical reading which was to play an important part in his theory of the novel" (pp. vii-viii). In 1725, Fielding left Eton and went to the University of Leiden for a short period of time in 172829. In the 1730s, he managed to build a career as a prominent playwright of the decade which came to an end in 1737 with the Licensing Act "which his own antigovernment plays helped to precipitate" (Rawson, 1996, "Henry Fielding," $p$. 120). Indeed, these plays contained overt and assertive attacks on Robert Walpole and his ministry. He signed these plays under the name of "Scriblerius Secundus," "thus allying himself with the "Scriblerian satirists, Swift, Pope and Gay" (Bree, 1996, p. 8) which also proves his affinity for their style. After the Licensing Act which banned political satire on the stage, Fielding ventured into prose and started to write for a living. He produced many novels including Shamela (1741), rather a novella, Joseph Andrews (1742), Jonathan Wild (1743) included in Miscellanies, Tom Jones (1749) and Amelia (1951).

The History of the Life of the late Mr. Jonathan Wild the Great, or rather simply Jonathan Wild, takes its subject matter from the life of a real-life figure Jonathan Wild (1682-1725), who was a very infamous gangster of the 1720s London or, in Martin Battestin's (2000) words, "the most notorious criminal of his day" (p. 162). Jonathan Wild was often referred to as the thief-taker, whose job, in general, "involved capturing everyone from housebreakers to highwaymen and testifying against them in court; a zeal for returning goods to their owners often proved compatible [. . .] with fencing stolen goods, organizing gangs of criminals, and turning over one's own close associates to the law, no matter that they were likely to be hanged for their offences" (Davidson, 2007, pp. 65-66). Such was his notoriety in his own lifetime as well as the period following his death that Wild achieved, as Davidson (2007) puts it, "almost mythic status (first as enforcer of the law, then as its abuser, and at last as its victim)" (p. 66). He was brought to trial and hanged in 1725; however, his infamous reputation was further strengthened in the works of the time including Daniel Defoe's The True and Genuine Account of The Life and Actions of the Late Jonathan Wild and John Gay's The Beggar's Opera (1728). His job, or rather business, as a thief-taker ran smoothly with his control of a body of thieves until his illegal dealings were revealed and brought to an end. Thus, as Claude Rawson (2008) notes, "[i]n satirical and polemical writings of the time, it was a wellestablished convention to use Wild's name when referring to Sir Robert Walpole, the Prime Minister. 'Great Man' [as also seen in the full title of Jonathan Wild], though capable of being applied to others, was also familiar sobriquet for Walpole [. . .]" (Introduction, p. xvi). Likewise, in a more assertive and direct way, John Edwin Wells (1913) notes that "[t]hroughout nearly twenty years preceding the appearance of Jonathan Wild, at least from 1725 to 1742, the Great Man in England was Robert Walpole" (p. 14). Wells continues to state with more certainty that "[e]ven the casual reader of the minor writings of the period knows that hundreds of pamphlets and thousands of periodical writings had habituated the public to the association of the term 'Great Man' [with Robert Walpole]" (p. 14). Indeed, since George I, the first Hanoverian king, heavily depended upon his ministers in the domestic affairs of the country, Robert Walpole came to the fore as the Prime Minister. In a sense, he became a surrogate for the king and dealt with the public and domestic affairs in his own corrupt way, to the displeasure of many. The corruption that pervaded his ministry and government came to be associated with that of Jonathan Wild, thereby resulting in the use of the name as well as the story of Wild as a pretext for lampooning Walpole. In this regard, Fielding's Jonathan Wild can be seen as a satire, as will be dealt with presently, mainly on the politics of Walpole, much as Fielding tries to make the reader believe in the Preface to Miscellanies that the intended satire in the novel was not on Walpole.

In the Preface of Miscellanies, Fielding reveals explicitly that he has no claim to the authenticity of the narrative of Jonathan Wild and simply states that he fictionalized what the real-life figure Wild could have done or performed but definitely did not do: "To confess the truth, my Narrative is rather of such Actions which he might have performed, or would, or should have performed, than what he really did; and may, in Reality, as well suit any other such great Man, as the Person himself whose Name it bears" $(1979$, p. 9). However, immediately after this, Fielding cautions the reader against not applying the satire to a specific individual, and, instead, recommends to take it as a general satire on the follies and vices prevailing in the society:

A second Caution I would give my Reader is, that as it is not a very faithful Portrait of Jonathan Wild himself, so neither is it intended to represent the Features of any other Person. Roguery, and not a Rogue, is my Subject; and as I have been so far from endeavoring to particularize any Individual, that I have with my utmost Art avoided it; so will any such 
Application be unfair in my Reader, especially if he knows much of the Great World, since he must then be acquainted, I believe, with more than one on whom he can fix the Resemblance. $(1979$, p. 9)

Indeed, we do not know for sure why Fielding was that much worried lest his work should be taken as a direct satire on Walpole, because, ironically, it was none other than Fielding himself who ridiculed and satirized Walpole and his ministry in his plays only a few years before. The only possible explanation of Fielding's attempts to prevent any association between Wild and Walpole is, as James A. Downie (2009) asserts, that "Walpole subsequently subscribed to ten sets of Fielding's Miscellanies on royal paper at a cost of twenty guineas. In the circumstances, it would have been ungrateful at the very least had Fielding attempted to represent the Life of Mr. Jonathan Wild the Great as a political satire at his most recent patron's expense" (p. 138). Taking into consideration the fact that, as previously mentioned, Fielding turned to prose to make a living after his career as a dramatist ended, it is only in this way comprehensible that Fielding avoided any particularization "with [his] utmost Art." Furthermore, quite ironically, Walpole subscribed to Miscellanies without knowing the content of it since the book was published by subscription which meant that the readers would pay the money in advance to have the book when it came out. No matter how hard Fielding tried to annul such associations between Walpole and the fictionalized Jonathan Wild, it was to no avail. As Martin Battestin (2000) suggests, "[s]uch disclaimers [in the Preface] notwithstanding, the identification of Walpole with Wild had been a commonplace of political writing for more than a decade. [Therefore,] [v]ery few of Henry Fielding's first readers could have failed to make the connection" (pp. 162-163).

The ironical and satirical tone of Fielding's Jonathan Wild (1893) is set by the narrator from the very outset with the narrator's emphasis on the difference between "greatness" and "goodness:"

no two things can possibly be more distinct from each other, for Greatness consists in bringing all Manner of Mischief on Mankind, and Goodness in removing it from them. It seems therefore very unlikely that the same person should possess them both; and yet nothing is more usual with writers, who find many instances of greatness in their favorite hero, than to make him a compliment of goodness into the bargain; and this, without considering that by such means they destroy the great perfection called uniformity of the character [. . . ]. (p. 3)

With this passage, Fielding insinuates that he will "adopt a favorite narrative strategy of Jonathan Swift, [that is] prais[ing] of the vice he means to excoriate: Jonathan Wild, the supreme villain, is meant to seem admirable, while his victim, Heartfree, the good man, is sneered at as a simpleton and weakling" (Battestin, 2000, p. 235). The narrator describes the greatness of Wild as a hero as follows:

In our hero there was nothing not truly great: he could, without the least abashment, drink a bottle with the man who knew he had the moment before picked his pocket; and, when he had stripped him of everything he had, never desired to do him any further mischief; for he carried good-nature to that wonderful and uncommon height that he never did a single injury to man or woman by which he himself did not expect to reap some advantage. (p. 37)

Each and every action Wild performs is satirized by way of contrasting what he does and does not. Wild shows his greatness not in pickpocketing the man with whom he drinks a bottle, but rather in "never desir[ing] to do any further mischief" or in never intending to do injury to a man or woman from whom he cannot extract a profit. The greatness of Wild's deeds is illustrated with many examples ranging across pickpocketing, whoring, drinking, deceiving, robbing, etc. A monologue of Wild's, as case in point, shows his fondness of "great" and "greatness" and gives a hint to the reader what he understands from it: "The art of policy is the art of multiplication, the degrees of greatness being constituted by those two little words more or less" (p. 51). And he continues to reason as such: "Mankind are first properly to be considered under two grand divisions, those that use their own hands, and those who employ the hands of others. The former are the base and rabble; the latter, the genteel part of the creation" (p. 51). In his categorization of humankind, Wild places himself apparently under the category of those who use not their hands but others' hands to achieve their "greatness." Indeed, throughout the first book of the novel, we witness Wild connive a plan and make one of his fellow thieves, named Bagshot, rob the Count La Ruse. Upon Bagshot's bringing back the booty, Wild indulges in an argument with Bagshot and tries to persuade him that he should waive his share and let Wild have the full possession of it since the plan belongs to Wild, not Bagshot. This metaphor of employing the hands of others is extended and fashioned later in the novel with underlying political innuendoes, as will be discussed later.

Another example in relation to Wild's "greatness" is Wild's persuading a Miss Straddle (a prostitute) to give a false testimony against a Thomas Fierce who is arrested and immediately put into Newgate prison. What is ironic here, after arranging this plan with Miss Straddle, Wild goes to see Fierce in the prison pretending to know nothing of the matter. 
Therefore, his "greatness" is in his dexterity to connive plans and deceive people to his own advantage, as the cynical narrator puts it:

\begin{abstract}
With such infinite Address, did this truly greatman know to play with the Passions of Men, and to set them at Variance with each other, and to work his own Purposes out of those Jealousies and Apprehensions, which he was wonderfully ready at creating, by Means of those great Arts, which the Vulgar call Treachery, Dissembling, Promising, Lying, Falsehood, \&c. but which are by great men summed up in the collective Name of Policy, or Politicks, or rather Pollitricks; an Art of which, as it is the highest Excellence of Human Nature, so perhaps, was our great man the most eminent Master. (p. 79)
\end{abstract}

The narrator, as Jenny Davidson (2007) argues, "sounds rather like one of Jonathan Swift's mad projectors, exposing (by celebrating qualities generally found odious) a genuinely sinister aspect of greatness and its philosophical underpinnings" (p. 68). The association of the figure of "Great Man" with vices and falsity continues throughout the narrative and, in addition, becomes much more discernible with the introduction of the Heartfrees in full contradistinction to the mischievous character of Jonathan Wild.

Wild haphazardly encounters his friend Heartfree on the street and immediately makes endearing advances showing a great regard for him - which Heartfree, as the good and naïve character of the narrative, readily believes in his sincerity since Wild is an old friend from school days. However, Wild seems to have some sincerely calculated insincerities near at hand for Heartfree. After robbing Heartfree, Wild arranges the arrest and imprisonment of Heartfree for his debts. Though he assures Heartfree that he will find the required bail for his release, Wild never shows up because, in the meantime, he managed to persuade Mrs Heartfree that she should go to Holland with him to protect the jewels and money of his husband and that his husband will come to Holland after he [Wild] procures the necessary money for the bail. Therefore, with the disappearance of Wild, Heartfree assures himself that Wild is the villain.

However, after many unfortunate incidents at sea, Wild eventually comes back to England and visits Heartfree in prison, and recounts falsely how he protected Heartfree's wife at sea from the French captain of the ship. Immediately after this, Heartfree's rage against Wild calms down and he starts once again to believe Wild's sincerity and friendship. Thus, the extremity of good-heartedness and frankness of Heartfree as opposed to the villainy of Wild is exalted, as previously mentioned, by praising Wild. However, Heartfree's pardoning Wild and reaffirming their friendship, as Aaron Charles Schneider (2011) emphasizes, "make [him] appear gullible to the point of foolishness [. . .] [since] Heartfree is in jail, his jewels have been stolen, and his wife has disappeared, all, the reader knows, at Wild's doing" (p. 96). Even though Heartfree is meant to appear as a foil to Wild, at times he seems to be rather a fool than a foil. In this regard, "it is virtually impossible that the reader not enjoy a critical laugh at Heartfree's expense when he quickly believes Wild's spurious explanation of events and then embraces him, attempting to comfort him in his feigned concern for the difficulties in which Heartfree finds himself" (Schneider, 2011, p. 96). Wild's taking good advantage of Heartfree's gullibility and naivety as opposed to Heartfree's good intentions for him lays bare the operation of the satire and, more significantly, the aim of Fielding, in Davidson's (2007) words, "to expose the general tendencies of human nature" (p. 67). There is this continual struggle throughout the narrative between "greatness" associated with any vice one can imagine and "goodness" affiliated with silliness and weakness, which demonstrates the important function of the Heartfrees in satirizing Wild. In a similar vein, William Irwin argues that "with the introduction of the Heartfrees, a dramatic pattern is superimposed upon the [narrative]. To be sure, little conflict ensues. For the most part, Wild, the embodiment of "greatness," acts against the Heartfrees ("goodness"), who receive his depredations not with repulsive efforts but with the uncomprehending passivity of innocence which eventually proves stronger than Wild's calculated villainy" (p. 177). What Irwin implies by "little conflict ensues" simply is that "greatness" slaps "goodness" hard in the face, and it just turns the other cheek. This passivity on Heartfree's part, on macrocosmic level, is extended to the general public who suffered passively at the hands of the corrupted politics of Robert Walpole.

In Wild's surreptitious doings, Fielding satirizes Robert Walpole, the first prime minister of Britain, who was in office from 1721 and 1742. The mischievous deeds Wild performs show parallelism to those of Walpole's ministry. The narrator, at the end of the novel, sums up Wild's character and actions which bear conspicuous resemblance to those of Walpole's ministry:

[. . .] when we see our hero, without the least assistance or pretence, setting himself at the head of a gang, which he had not any shadow of right to govern; if we view him maintaining absolute power, and exercising tyranny over a lawless crew, contrary to all law but that of his own will; if we consider him setting up an open trade publickly in defiance not only of the laws of his country but of the common sense of his countrymen; if we see him first contriving the robber of others, and again the defrauding the very robbers of that booty, which they had ventured their necks to acquire [ . . ]. (p. 223) 
If we are to check the correlations between this passage and Walpole's ministry, we can easily state that just as Wild positions himself at the head of a gang that he has no right to govern, Walpole came to the fore as the prime minister, which "was not an official title but rather a nasty epithet" (Davidson, 2007, p. 66) at that time, and exerted his power to control all the affairs related to the state affairs along with the utmost corruption ranging across bribery, patronage, and selling of offices. As Isaac Kramnick (1968) asserts, "Walpole solidified his power by using the Crown's tremendous power of patronage; both Georges usually followed his advice in their appointments. From recipients of places and their relatives Walpole exacted allegiance to his leadership in the Commons [. . .]" (p. 111). Additionally, Walpole "used the patronage of the Crown to help secure election victories" and, therefore, "[a]fter an election, offices, large or small, would be hawked to relatives, friends, and dependents of relatives and friends of successful candidates on the understanding that the beneficiary's political influence would be at Walpole's disposal" (Kramnick, 1968, pp. 111112).

Previously, fencing stolen goods, organizing gangs and turning in one's own associate were numbered among what Wild's job as a thief-taker required. By the same token, we can say that fencing stolen goods corresponds to Walpole's selling government jobs and offices. Also, "[j]ust as the victims of Wild's thievery must pay for what is rightfully theirs," as Schneider (2011) notes, "prospective government employees, after granting Walpole and his henchmen the right to run the government, must pay for the privilege of participating in it" (p. 116). The similarities between the two are carried to another level in the chapter six of Book II, entitled "Of Hats" which is fraught with political undertones. The beginning of this chapter reads as follows:

Wild had now got together a very considerable gang, composed of undone gamesters, ruined bailiffs, broken tradesmen, idle apprentices, attorneys' clerks, and loose and disorderly youth, who [. . . were willing to live luxuriously without labour. As these persons wore different principles, i.e. hats, frequent dissensions grew among them. There were particularly two parties, viz., those who wore hats fiercely cocked, and those who preferred the nab or trencher hat [...]. (p. 80)

These two parties, according to the narrator, went by the names of "cavaliers and tory rory ranter boys" and "wags, roundheads, shakebags, old-nolls" respectively (p. 80). These name tags simply refer to the two extant parties of the time: the Tories (Royalists) and the Whigs (Parliamentarians). Though the contention between the two parties was at its highest point in the latter half of the $17^{\text {th }}$ century, it subsided in the $18^{\text {th }}$ century insomuch as "[t]he Tories [. . .] sulked in their country houses or sat independently in the back benches of the Commons, aloof from the game of politics" (Kramnick, 1968, p. 111). However, the following passage from the novel suggests that the conflict between the two parties was still high, and thereby leading Wild to assert:

Gentlemen, I am ashamed to see men embarked in so great and glorious an undertaking, as that of robbing the public, so foolishly and weakly dissenting among themselves. (p. 81)

You do wisely, therefore, when in a crowd, to amuse the mob by quarrels on such accounts, that while they are listening to your jargon you may with the greater ease and safety pick their pockets: but surely to be in earnest, and privately to keep up such a ridiculous contention among yourselves, must argue the highest folly and absurdity. When you know you are all prigs, what difference can a broad or a narrow brim create? (p. 81)

Indeed, Fielding rightly suggests that both parties are representative of the general public in the parliament under the leadership of Robert Walpole. Hence, it does not matter whether the parties differ in their principles as long as they are "prigs" and rob the public.

On the other, hand, if we remember the passivity of Heartfree against Wild, we can also state that the public participates in their own oppression, or rather being robbed, by electing Walpole. This is greatly exemplified in the Newgate Electioneering scene. In this scene, Roger Johnson, an actual criminal just like Wild, appears as the head of the thieves in Newgate and is challenged by Wild who wants to be the head. They go for an election and the debtors (the ones imprisoned for their debts) also participate in the election campaigns as the representative of the general public to choose ironically which prig, or thief, should be the leader. What they do not understand is that they are supplanting one prig with another which, consequently, will result in their being robbed once more. After Wild is chosen as the leader, he strips Johnson of all his money but refuses to share it among his supporters who are enraged greatly since they helped Wild win the election. This was the case with Walpole himself who had the support of many and won the British general election of 1727 but distributed the government offices and jobs not to his supporters but his friends and relatives. Then a grave man among the prisoners, as the narrator says, rightfully summed up the whole situation, addressing them as follows: 


\begin{abstract}
Nothing sure can be more justly ridiculous than the conduct of those who should lay the lamb in the wolfs way, and then should lament his being devoured. What a wolf is in a sheep-fold, how little would it avail the simple flock to expel him and place another in his stead! Of the same benefit to us is the overthrowing one prig [Johnson] in favour of another [Wild] [ . . ]. Perhaps some would say, Is it then our duty tamely to submit to the rapine of the prig who now plunders us for fear of an exchange? Surely no: but I answer, It is better to shake the plunder off than to exchange the plunderer. (p. 169)
\end{abstract}

Indeed, along with the satirical treatment of Walpole's politics, the general public in the embodiment of Heartfree suffers from his passivity at the hands of a cruel and ruthless treatment in the embodiment of Wild. As can be clearly understood from the passages quoted and explored above, Fielding "attacked Walpole as exemplifying that against which his whole nature revolted as the exemplar of the unjust glorification of perversion of political activity and of baseness and selfishness of personal life and ideal" (Wells, 1913, p. 55). In this regard, Fielding's rigorous disclaimers to the contrary notwithstanding, it is impossible to bypass the political innuendoes and undertones available in the text.

In conclusion, though Fielding was regarded as one of the eminent playwrights of his time, ironically, he is today considered one of the masters of English fiction. His turn from playwriting to prose, as we have seen, did not prevent him from employing his satire on the politics of his day which was the driving motive behind his plays and which eventually banned him from the stages with the Licensing Act. Rather, this enforced change from drama to prose fiction "gave him the needed freedom and allowed him to express effectively ideas and attitudes which in earlier works had come forth either unnaturally or formlessly" (Irwin, 1946, p. 180). Indeed, upon combining his sharp eye for the follies of his age with his satirical attitude, Fielding managed to produce the best examples of satirical prose fiction which are still widely read today.

\title{
References
}

Battestin, M. C. (2000). A Henry Fielding Companion. London: Greenwood Press.

Bree, L. (1996). Henry Fielding's Life. In Rawson, C. (Ed.), The Cambridge Companion to Henry Fielding (pp. 3-16). Cambridge: Cambridge University Press.

Davidson, J. (2007). Jonathan Wild. In Rawson, C. (Ed.), The Cambrige Companion to Henry Fielding (pp. 65- 79). Cambridge: Cambridge University Press.

Downie, J.A. (2009). A Political Biography of Henry Fielding. London: Pickering \& Chatto.

Fielding, H. (1950). Author's Preface. In Henry Fielding, Joseph Andrews (pp. xxxi-xxxix). New York: Random House.

Fielding, H. (2011). Preface. In H. K. Miller (Ed.), Miscellanies by Henry Fielding, Esq (pp. 3-15) Oxford: Clarendon Press.

Fielding, H. (1893). The History and the Life of the Late Mr. Jonathan Wild the Great. London: J.M. Dent \& Co.

Irwin, W.R. (1946). Satire and Comedy in the Works of Henry Fielding. ELH 13 (3), 168-188.

Jones, H. M. (1950). Introduction. In Henry Fielding, Joseph Andrews (pp. 5-22). New York: Random House.

Kramnick, I. (1968). Brolingbroke and His Circle: The Politics of Nostalgia in the Age of Walpole. New York: Cornell University.

Rawson, C. (1996). Henry Fielding. In Richetti, J. (Ed.), The Cambridge Companion to the Eighteenth Century Novel (pp. 120-152). Cambridge: Cambridge University Press.

Rawson, C. (2008). Introduction. In Henry Fielding, Jonathan Wild (pp. ix-xxxii). Oxford: Oxford University Press.

Schneider, A. C. (1986). From Providence to Prudence: Ethical Constructs and Historical Context in the Works of Henry Fielding. Retrieved from ProQuest Dissertations and Theses.

Wells, J. E. (1913). Fielding's Political Purpose in Jonathan Wild. PMLA 28 (1), 1-55. 